\title{
Variation in the Ecology of Medical Care
}

George E. Fryer, Jr, $P b D^{1}$

Larry A. Green, $M D^{1}$

Susan M. Dovey, $P b D^{1}$

Barbara P. Yawn, $M D^{2}$

Robert L. Pbillips, $M D^{1}$

David Lanier, $M D^{3}$

'The Robert Graham Center, American Academy of Family Physicians,

Washington, DC

${ }^{2}$ Department of Research, Olmsted Medical Center, Rochester, Minn

${ }^{3}$ The Agency for Healthcare Research and Quality, Rockville, Md
Conflicts of interest: none reported

\section{CORRESPONDING AUTHOR:}

George E. Fryer, PhD

The Robert Graham Center: Policy Studies in Family Practice and Primary Care 1350 Connecticut Ave, NW, Suite 950 Washington, DC 20036

Efryer@aafp.org

\begin{abstract}
BACKGROUND We wanted to quantify how the location in which medical care is delivered in the United States varies with the sociodemographic characteristics and health care arrangements of the individual person.

Methods Data from the 1996 Medical Expenditures Panel Survey (MEPS) were used to estimate the number of persons per 1,000 per month in 1996 who had at least 1 contact with physicians' offices, hospital outpatient departments, or emergency departments, hospitals, or home care. These data were stratified by age, sex, race, ethnicity, household income, education of head of household, residence in or out of metropolitan statistical areas, having health insurance, and having a usual source of care.
\end{abstract}

Results Physicians' offices were overwhelmingly the most common site of health care for all subgroups studied. Lacking a usual source of care was the only variable independently associated with a decreased likelihood of care in all 5 settings, and lack of insurance was associated with lower rates of care in all settings but emergency departments. Generally, more complicated patterns emerged for most sociodemographic characteristics. The combination of having a usual source of care and health insurance was especially related to higher rates of care in all settings except the emergency department.

Conclusion Frequency and location of health care delivery varies substantially with sociodemographic characteristics, insurance, and having a usual source of care. Understanding this variation can inform public consideration of policy related to access to care.

Ann Fam Med 2003;1:81-89. DOI: 10.1370/afm.52

\section{INTRODUCTION}

7 he relationships between people and their health care environments have been known as the ecology of medical care since the landmark conceptualization by White et al was published in $1961 .{ }^{1}$ Displayed as a series of boxes depicting the proportions of persons using health care services in particular settings in an average month, this framework has influenced thinking about the organization of health care, research, and education for 40 years. ${ }^{2-8} \mathrm{~A}$ recent update showed the relative stability of estimates of health care use in different settings, ${ }^{9}$ even with major changes in the US health care system during a 40-year period. ${ }^{10-17}$

The ecology model, despite its usefulness in conceptualizing health care delivery in the United States, has never been applied to understanding the important problem of disparities in health care delivery. It is widely known that health ${ }^{18-33}$ and health care ${ }^{34-44}$ vary substantially with sociodemographic characteristics. How the location of health care delivery differs with the age, sex, race, ethnicity, income, education, insurance, location of residence, and having a usual source of care is much less well understood but might be helpful in conceptualizing system redesign solutions to health care disparities. These variations are potentially important 
in formulating and assessing health policy objectives, such as access to appropriate care, disease prevention and health promotion, and equity. Providing everyone with insurance $e^{45-52}$ and a usual source of care ${ }^{53-63}$ is the policy arrangement most widely studied in the past as means for attaining these objectives.

Advances in US national health care surveys now permit national inferences based on analyses of subsets of the population with adjustment of measurements to isolate effects of personal sociodemographic characteristics and health care arrangements. Thus, a potentially important extension of the ecology model is now possible as recommended by its founders in their original work in 1961: to understand ecological relationships as a prelude to further examination and to guide future assessments of the adequacy and appropriateness of existing health care resources. ${ }^{1}$

We first aimed in this study to quantify the variation among subsets of the US population receiving care in an average month in each of 5 health care settings: physicians' offices, outpatient clinics, emergency departments, hospitals, and at home. Then, to help account for interactions among available variables and provide additional information for policy purposes, we used logistic regressions to estimate the likelihood of receiving care in these settings attributable to age, sex, race, ethnicity, residence, education of head of household, household income, having health insurance, and having a usual source of care. Finally, we examined the potentially most policy-relevant association of having both insurance and a usual source of care on receiving care in each setting.

\section{METHODS}

This study was approved by the Olmstead Medical Center Institutional Review Board in October 2000.

\section{Study Population}

Data for the US civilian noninstitutionalized population were taken from the 1996 Medical Expenditure Panel Survey (MEPS) sponsored by the Agency for Healthcare Research and Quality (AHRQ) ${ }^{64} \mathrm{MEPS}$ is an ongoing nationally representative survey with a rotating panel design that enables longitudinal study of a large cohort for a 2-year period. Its sample consists of households and individuals that had taken part in a previous National Health Interview Survey (NHIS). In this study, household component records characterizing individuals and families were linked to data from event files profiling their health care encounters in calendar year 1996, the same year used for the update of the original ecology of medical care. ${ }^{9}$ MEPS records are weighted to permit the calcu- lation of national estimates, usually with small standard errors.

\section{Study Variables}

Dependent variables consisted of the number of persons per 1,000 who in a typical month received health care in each of 5 settings described in MEPS: (1) a physician's office, (2) an outpatient clinic, (3) a hospital emergency department, (4) a hospital, and (5) their own home. These estimates were compiled from MEPS health event files.

The following predictor variables used in multivariate analyses were taken from MEPS household files:

1. Age -6 age-groups used by AHRQ for reporting purposes

2. Sex - female or male

3. Race -4 racial groups, with Aleutians and Eskimos omitted because of large standard errors and small sample size

4. Ethnicity - Hispanic or not Hispanic

5. Resident - resident of a metropolitan statistical area (MSA) county or a resident of a non-MSA county

6. Education -3 categories for highest degree obtained by head of household

7. Household income - reported family income divided by the federal poverty line based on family size and composition, with the resulting percentages grouped into 5 categories

8. Health insurance - having any health insurance without regard to adequacy of coverage, or having no health insurance

9. Usual source of care - response to the question: "Is there a particular doctor's office, clinic, health center, or other place that you go to if you are sick or need advice about your health?"

We excluded MEPS respondents if data were missing for them on any of the study variables. Less than $2.8 \%$ of the 21,571 surveyed were excluded by this criterion. The study groups were not further subdivided for other considerations, such as health status or presence of particular diseases or conditions.

\section{Analysis Strategy}

Descriptive analyses were performed as in previous studies using the ecology model, ${ }^{9}$ estimating the number of persons per 1,000 of the civilian noninstitutionalized US population in 1996 who in 1 month received health care 1 or more times in each of the 5 settings. We first created person-month records, 251,700 in total for 1996 MEPS respondents. A person-month was the unit of analysis and indicated receipt of services in a health care setting at least once in a month, but not the total number of times care was received in the setting during the month. The individ- 
ual's survey weight was applied to each person-month, and the result was multiplied by 1,000 to produce estimates. We then evaluated potential predictor variables for inclusion in multivariate analyses. Separate logistic regressions were used to derive the adjusted odds ratios of the respective predictor variables on the receipt of care in each setting. In effect, we assessed the association of every variable with receiving care in each of the 5 health care settings while statistically controlling for all other predictor variables. For each variable, the most populated category was designated the reference group in the development of adjusted odds ratios. Finally, we estimated the number of persons per 1,000 in each of the 4 combined categories of whether insured and had a usual source of care, and received health care 1 or more times in 1 month in the 5 settings. All analyses were done with SUDAAN to adjust variance estimates that were the result of MEPS survey design complexity, particularly the substantial oversampling of certain racial and ethnic minorities.

\section{RESULTS}

The variation in the receipt of any service in each setting in a typical month is shown in Table 1 . The ad justed odds ratios of receiving care in each setting in a typical month, isolated to each variable and controlling for all other predictor variables, are shown in Table 2. Selected findings are organized by the predictor variables, first noting variation and then odds ratios. The 5 logistic regression models developed, 1 for each health care setting, were all strongly predictive $(P<.0001)$.

\section{Age}

After 5 years of age, being older was associated with progressively larger proportions of persons receiving care in all settings except emergency departments, where larger proportions of young children and young adults aged 18 to 24 years received care than other age-groups, and physicians' offices, where similar proportions of children aged 5 to 17 years and young adults aged 18 to 24 years were seen. Compared with other age-groups, a larger proportion of persons aged 65 years or older received care in all settings except emergency departments.

A person's age was a strong independent predictor of receiving health care in all settings. After the age of 5 years, the likelihood of receiving care increased with greater age in all settings except emergency departments

\section{Sex}

A smaller proportion of those who were male received care in all settings except emergency departments, where similar proportions received care.
Being male was also an independent predictor of decreased likelihood of receiving services in all settings except emergency departments.

\section{Race}

Similar proportions of African Americans and whites received services in emergency departments, hospitals, and their homes, but smaller proportions of African Americans received care in hospital outpatient departments and physicians' offices. A smaller proportion of Asians than either African Americans or whites received care in all settings except physicians' offices, where a proportion similar to African Americans received care. American Indians differed most from African Americans and whites in hospital outpatient departments, where a smaller proportion were seen, and in emergency departments, where a larger proportion were seen.

A person's race was not independently useful in predicting the likelihood of receiving care in the hospital or home, but being African American or Asian did predict a lower likelihood of receiving care in all outpatient settings. American Indians and whites had similar likelihood of care in all settings.

\section{Ethnicity}

A smaller proportion of Hispanics than non-Hispanics received care in all settings except the emergency department, where similar proportions received care.

A person's ethnicity did not affect being hospitalized or receiving care at home, but being Hispanic independently diminished the likelihood of receiving care in all outpatient settings.

\section{Household Income}

Larger proportions of poor persons received care in emergency departments, hospitals, and their homes; smaller proportions received care in physicians' offices; and there was little difference in received care in hospital outpatient departments.

Income of the household where a person lived did not independently affect the likelihood of receiving care in outpatient departments or physicians' offices. Living in a poorer household was associated with increased likelihood of hospitalization and receipt of care in emergency departments and at home.

\section{Education of Head of Household}

With increasing educational attainment of the head of household, larger proportions of persons were seen in physicians' offices and smaller proportions were hospitalized or seen in emergency departments. There was relatively little variation by education in the proportions receiving care in outpatient departments, but living with 
a head of household with no degree was associated with a much larger proportion of receiving home care.

The level of educational attainment of the head of household where a person lived did not affect the likelihood of receiving care in outpatient departments or at home. Greater educational attainment was associated with diminished likelihood of hospitalization and emergency department care and an increased likelihood of receiving care in physicians' offices.

\section{Residence}

A larger proportion of persons living outside MSAs received care in all settings except physicians' offices, where they were similar in proportions of persons living in MSAs.

Whether a person lived in or outside an MSA had little independent effect on receipt of care, although there was a small decrease in likelihood of receiving care in physicians' offices for persons living outside MSAs.

\section{Table 1. Variation in the Number of Persons Who Received Care in Different Health Care Settings in the United States in 1996 (persons per 1,000/mo), by Sociodemographic Characteristics.}

\begin{tabular}{|c|c|c|c|c|c|}
\hline Demographic Characteristic & $\begin{array}{l}\text { Hospital Stays } \\
\text { No. (SE) }\end{array}$ & $\begin{array}{c}\text { Outpatient } \\
\text { Department Visits } \\
\text { No. (SE) }\end{array}$ & $\begin{array}{c}\text { Emergency } \\
\text { Department Visit } \\
\text { No. (SE) }\end{array}$ & $\begin{array}{l}\text { Office Visits } \\
\text { No. (SE) }\end{array}$ & $\begin{array}{c}\text { Home } \\
\text { Health Care } \\
\text { No. (SE) }\end{array}$ \\
\hline \multicolumn{6}{|l|}{ Age (y) } \\
\hline$<5$ & $5.6(0.9)$ & $11.8(1.2)$ & $18.6(1.3)$ & $243.5(7.2)$ & $2.2(0.9)$ \\
\hline 5-17 & $2.4(0.4)$ & $7.0(0.7)$ & $11.4(0.6)$ & $144.6(3.5)$ & $1.7(0.6)$ \\
\hline $18-24$ & $6.8(0.8)$ & $9.9(1.1)$ & $18.0(1.5)$ & $140.1(5.2)$ & $2.0(0.9)$ \\
\hline $25-44$ & $6.8(0.4)$ & $17.0(1.0)$ & $2.3(0.5)$ & $191.8(3.8)$ & $4.4(0.8)$ \\
\hline $45-64$ & $9.0(0.6)$ & $32.7(1.7)$ & $10.8(0.6)$ & $262.7(5.0)$ & $9.0(1.2)$ \\
\hline$\geq 65$ & $20.2(1.1)$ & $50.8(2.6)$ & $14.0(0.8)$ & $383.8(7.4)$ & $73.6(4.7)$ \\
\hline \multicolumn{6}{|l|}{ Sex } \\
\hline Female & $9.0(0.4)$ & $25.0(1.1)$ & $13.3(0.4)$ & $255.5(3.4)$ & $17.4(1.2)$ \\
\hline Male & $6.9(0.4)$ & $17.7(0.8)$ & $12.6(0.5)$ & $181.0(3.1)$ & $8.2(0.9)$ \\
\hline \multicolumn{6}{|l|}{ Race } \\
\hline White & $8.2(0.3)$ & $23.0(0.8)$ & $13.1(0.4)$ & $232.9(3.1)$ & $13.0(0.9)$ \\
\hline African American & $7.2(0.8)$ & $15.7(1.6)$ & $13.2(0.9)$ & $154.0(4.4)$ & $14.3(2.1)$ \\
\hline Asian Pacific Islander & $4.4(0.8)$ & $10.0(2.6)$ & $5.1(1.1)$ & $153.0(10.1)$ & $6.3(2.8)$ \\
\hline American Indian & $7.2(2.0)$ & $11.3(2.2)$ & $21.1(3.6)$ & $182.9(23.1)$ & $15.1(8.3)$ \\
\hline \multicolumn{6}{|l|}{ Ethnicity } \\
\hline Non-Hispanic & $8.1(0.3)$ & $22.6(0.8)$ & $3.0(0.4)$ & $227.0(3.0)$ & $13.7(0.9)$ \\
\hline Hispanic & $6.7(0.6)$ & $12.1(1.1)$ & $12.9(0.9)$ & $155.7(5.2)$ & $7.0(1.1)$ \\
\hline \multicolumn{6}{|l|}{$\begin{array}{l}\text { Household income as percent } \\
\text { of federal poverty level }\end{array}$} \\
\hline$\geq 400 \%$ & $6.2(0.4)$ & $22.6(1.1)$ & $9.5(0.5)$ & $246.5(4.4)$ & $7.5(1.0)$ \\
\hline $200 \%-399 \%$ & $6.9(0.4)$ & $19.4(0.9)$ & $11.8(0.5)$ & $207.5(3.6)$ & $7.3(1.1)$ \\
\hline $125 \%-199 \%$ & $10.0(0.8)$ & $21.8(1.8)$ & $15.8(1.0)$ & $205.1(5.7)$ & $19.2(2.9)$ \\
\hline $100 \%-124 \%$ & $9.6(1.3)$ & $24.8(3.9)$ & $17.6(2.1)$ & $196.3(9.0)$ & $31.6(5.5)$ \\
\hline$<100 \%$ & $11.3(0.9)$ & $21.5(1.7)$ & $18.8(1.0)$ & $202.8(5.6)$ & $25.5(2.8)$ \\
\hline \multicolumn{6}{|l|}{ Education of head of household } \\
\hline No degree & $11.0(0.8)$ & $23.8(1.6)$ & $17.1(0.9)$ & $201.5(5.4)$ & $29.6(3.0)$ \\
\hline Graduated high school, GED & $8.1(0.4)$ & $21.1(0.9)$ & $13.4(0.5)$ & $210.7(3.6)$ & $10.4(0.9)$ \\
\hline Degree beyond high school & $5.8(0.4)$ & $20.5(1.2)$ & $9.9(4.3)$ & $243.6(4.8)$ & $7.5(1.1)$ \\
\hline \multicolumn{6}{|l|}{ Residence location } \\
\hline MSA & $7.6(0.3)$ & $20.3(0.7)$ & $12.3(0.4)$ & $220.7(3.0)$ & $11.6(0.9)$ \\
\hline Non-MSA & $9.2(0.8)$ & $25.7(2.2)$ & $15.8(0.9)$ & $213.2(6.6)$ & $18.2(2.3)$ \\
\hline \multicolumn{6}{|l|}{ Insurance status } \\
\hline Insured & $8.7(0.4)$ & $23.5(0.9)$ & $12.9(0.4)$ & $239.7(3.0)$ & $15.0(1.0)$ \\
\hline Uninsured & $3.9(0.5)$ & $11.0(1.0)$ & $13.3(0.8)$ & $116.6(3.9)$ & $2.8(0.9)$ \\
\hline \multicolumn{6}{|l|}{ Usual source of care } \\
\hline A usual source of care & $8.7(0.3)$ & $24.1(0.9)$ & $13.5(0.4)$ & $244.6(3.1)$ & $14.5(1.0)$ \\
\hline No usual source of care & $4.6(0.5)$ & $8.8(0.8)$ & $10.3(0.6)$ & $99.2(3.8)$ & $5.4(1.2)$ \\
\hline
\end{tabular}




\section{Having Health Insurance}

Smaller proportions of the uninsured persons were seen in all settings except emergency departments, where uninsured and insured persons received care in similar proportions.

Independent of the other characteristics, a person without insurance was much less likely to receive care in all settings except emergency departments.

Table 2. Adjusted Odds Ratios That a Person With Particular Characteristics Received Health Care in Selected Settings in the United States in a Typical Month in 1996.

\begin{tabular}{|c|c|c|c|c|c|}
\hline $\begin{array}{l}\text { Demographic } \\
\text { Characteristic }\end{array}$ & $\begin{array}{l}\text { Hospital Stays } \\
\text { OR ( } 95 \% \mathrm{CI})\end{array}$ & $\begin{array}{l}\text { Outpatient } \\
\text { Department Visits } \\
\text { OR }(95 \% \mathrm{Cl})\end{array}$ & $\begin{array}{c}\text { Emergency } \\
\text { Department Visits } \\
\text { OR }(95 \% \mathrm{Cl})\end{array}$ & $\begin{array}{l}\text { Office Visits } \\
\text { OR }(95 \% \mathrm{CI})\end{array}$ & $\begin{array}{l}\text { Home Health } \\
\text { Care Visits } \\
\text { OR (95\% Cl) }\end{array}$ \\
\hline \multicolumn{6}{|l|}{ Age $(y)$} \\
\hline$<5$ & $0.51(0.39-0.67)^{*}$ & $0.65(0.52-0.83)^{*}$ & $.38(1.16-1.63)^{*}$ & $2.41(1.99-2.91)^{*}$ & $0.51(0.27-0.96)^{\dagger}$ \\
\hline $5-17$ & $0.27(0.20-0.35)^{*}$ & $0.42(0.35-0.50)^{*}$ & $0.87(0.77-0.99)^{\dagger}$ & $0.83(0.75-0.92)^{*}$ & $0.29(0.16-0.52)^{*}$ \\
\hline $18-24$ & $1.03(0.79-1.34)$ & $0.66(0.54-0.81)^{*}$ & $1.47(1.22-1.76)^{*}$ & $0.88(0.76-1.03)$ & $0.50(0.24-1.04)$ \\
\hline $25-44$ & 1.00 & 1.00 & 1.00 & 1.00 & 1.00 \\
\hline $45-64$ & $1.13(0.96-1.32)$ & $1.78(1.57-2.02)^{*}$ & $0.86(0.75-0.99)^{\dagger}$ & $1.40(1.25-1.56)^{*}$ & $1.64(1.16-2.32)^{\ddagger}$ \\
\hline$\geq 65$ & $2.07(1.73-2.49)^{*}$ & $2.79(2.39-3.26)^{*}$ & $0.97(0.84-1.13)$ & $2.98(2.50-3.54)^{*}$ & $8.28(6.15-11.14)^{*}$ \\
\hline \multicolumn{6}{|l|}{ Sex } \\
\hline Female & 1.00 & 1.00 & 1.00 & 1.00 & 1.00 \\
\hline Male & $0.73(0.65-0.82)^{*}$ & $0.74(0.67-0.81)^{*}$ & $1.00(0.91-1.10)$ & $0.55(0.51-0.59)^{*}$ & $0.63(0.52-0.77)^{*}$ \\
\hline \multicolumn{6}{|l|}{ Race } \\
\hline White & 1.00 & 1.00 & 1.00 & 1.00 & 1.00 \\
\hline African American & $0.91(0.75-1.10)$ & $0.73(0.61-0.86)^{*}$ & $0.83(0.72-0.96)^{\dagger}$ & $0.62(0.55-0.69)^{*}$ & $1.06(0.80-1.41)$ \\
\hline Asian Pacific Islander & $0.73(0.49-1.08)$ & $0.50(0.32-0.79)^{*}$ & $0.38(0.24-0.60)^{*}$ & $0.55(0.43-0.71)^{*}$ & $0.68(0.37-1.26$ \\
\hline American Indian & $0.93(0.53-1.63)$ & $0.89(0.55-1.43)$ & $1.42(0.96-2.11)$ & $0.77(0.51-1.18)$ & $1.62(0.70-3.72)$ \\
\hline \multicolumn{6}{|l|}{ Ethnicity } \\
\hline Non-Hispanic & 1.00 & 1.00 & 1.00 & 1.00 & 1.00 \\
\hline Hispanic & $1.03(0.86-1.24)$ & $0.72(0.61-0.86)^{*}$ & $0.80(0.70-0.93) \neq$ & $0.79(0.71-0.89)^{*}$ & $0.77(0.55-1.07)$ \\
\hline \multicolumn{6}{|l|}{$\begin{array}{l}\text { Household income } \\
\text { as percent of federal } \\
\text { poverty level }\end{array}$} \\
\hline$\geq 400 \%$ & 1.00 & 1.00 & 1.00 & 1.00 & 1.00 \\
\hline $200 \%-399 \%$ & $1.13(0.97-1.31)$ & $0.97(0.86-1.09)$ & $1.18(1.04-1.35)^{\dagger}$ & $0.90(0.80-1.01)$ & $1.05(0.77-1.43)$ \\
\hline $125 \%-199 \%$ & $1.68(1.38-2.04)^{*}$ & $1.05(0.90-1.23)$ & $1.47(1.26-1.71)^{*}$ & $0.87(0.75-1.01)$ & $1.84(1.27-2.66)^{\ddagger}$ \\
\hline $100 \%-124 \%$ & $1.69(1.27-2.24)^{*}$ & $1.17(0.91-1.49)$ & $1.38(1.09-1.74)^{\ddagger}$ & $0.96(0.77-1.20)$ & $3.32(2.10-5.24)^{*}$ \\
\hline$<100 \%$ & $2.04(1.69-2.46)^{*}$ & $1.13(0.96-1.34)$ & $1.80(1.52-2.12)^{*}$ & $1.00(0.86-1.17)$ & $2.85(2.03-4.01)^{*}$ \\
\hline \multicolumn{6}{|l|}{$\begin{array}{l}\text { Education of head } \\
\text { of household }\end{array}$} \\
\hline No degree & $1.09(0.92-1.30)$ & $0.96(0.84-1.11)$ & $1.13(0.99-1.30)$ & $0.77(0.68-0.88)^{*}$ & $1.24(0.98-1.58)$ \\
\hline $\begin{array}{l}\text { Graduated high school, } \\
\text { GED }\end{array}$ & 1.00 & 1.00 & 1.00 & 1.00 & 1.00 \\
\hline $\begin{array}{l}\text { Degree beyond high } \\
\text { school }\end{array}$ & $0.82(0.71-0.96)^{\dagger}$ & $0.98(0.87-1.10)$ & $0.84(0.76-0.94) \neq$ & $1.39(1.24-1.56)^{*}$ & $1.22(0.91-1.64)$ \\
\hline \multicolumn{6}{|l|}{ Residence location } \\
\hline MSA & 1.00 & 1.00 & 1.00 & 1.00 & 1.00 \\
\hline Non-MSA & $1.04(0.89-1.21)$ & $1.13(0.96-1.33)$ & $1.13(0.99-1.30)$ & $0.88(0.79-0.99)^{\dagger}$ & $1.15(0.94-1.42)$ \\
\hline \multicolumn{6}{|l|}{ Insurance status } \\
\hline Insured & 1.00 & 1.00 & 1.00 & 1.00 & 1.00 \\
\hline Uninsured & $0.50(0.39-0.65)^{*}$ & $0.66(0.56-0.78)^{*}$ & $0.93(0.81-1.06)$ & $0.55(0.49-0.62)^{*}$ & $0.48(0.28-0.83)^{\ddagger}$ \\
\hline \multicolumn{6}{|l|}{ Usual source of care } \\
\hline Has a usual source of care & 1.00 & 1.00 & 1.00 & 1.00 & 1.00 \\
\hline No usual source of care & $0.57(0.46-0.71)^{*}$ & $0.43(0.36-0.50)^{*}$ & $0.73(0.64-0.84)^{*}$ & $0.28(0.25-0.31)^{*}$ & $0.58(0.40-0.86)^{\ddagger}$ \\
\hline \multicolumn{6}{|c|}{ 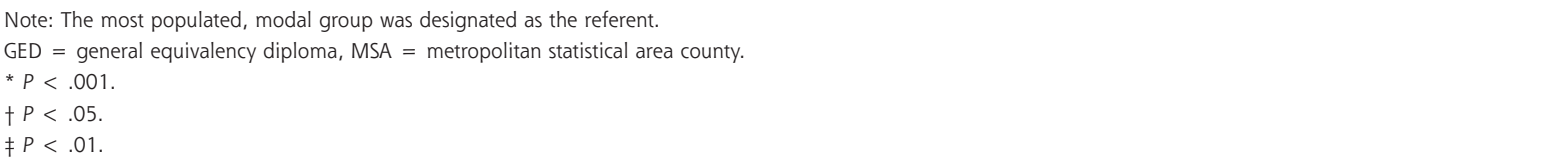 } \\
\hline
\end{tabular}




\section{Having a Usual Source of Care}

A larger proportion of persons having a usual source of care received care in all 5 settings, compared with those who did not have a usual source of care.

Independent of the other characteristics, a person without a usual source of care was less likely to receive care in all settings.

\section{Having Health Insurance and a Usual Source of Care}

Table 3 indicates that persons with insurance and a usual source of care were more likely to have received care in all settings but emergency departments compared with persons without either or absent both of these health care arrangements.

\section{DISCUSSION}

This analysis focused on the noninstitutionalized civilian population of the United States in 1996, not diseases or sufficiency of services, to show the variation in how individuals actually participated during a typical month in 5 health care settings. Considerable variation was found attributable to (1) usual source of care and insurance coverage, which are particularly amenable to health policy interventions $;$ (2) personal circumstances with potential policy implications (residence in MSA vs non-MSA county, education, and income), and (3) personal traits (age, sex, race, and ethnicity) that identify population groups with different patterns of participation in some settings. When compared with other study settings, the physician's office was the location in which overwhelmingly larger numbers of persons, for all subgroups studied, interacted with health care in a typical month. It is therefore the setting that has the potential to affect the largest number of persons from all sociodemographic strata in the United States.

Adjusting for the effects of the other 8 predictor variables, only 1 variable, having a usual source of

\section{Table 3. Variation in the Ecology of Medical Care Associated with Having Health Insurance or a Usual Source of Care in 1996 in the United States}

\begin{tabular}{lcccc}
\hline $\begin{array}{l}\text { Received Care } \\
\text { in This Setting }\end{array}$ & $\begin{array}{c}\text { Neither } \\
\text { Insurance or } \\
\text { Usual Source }\end{array}$ & $\begin{array}{c}\text { Only } \\
\text { Insurance }\end{array}$ & $\begin{array}{c}\text { Only Usual } \\
\text { Source }\end{array}$ & $\begin{array}{c}\text { Both } \\
\text { Insurance and } \\
\text { Usual Source }\end{array}$ \\
Physician office & 62 & 119 & 149 & 258 \\
Hospital outpatient & 5 & 11 & 14 & 25 \\
Emergency department & 10 & 10 & 15 & 13 \\
Home & 2 & 8 & 3 & 16 \\
Hospital & 2 & 8 & 3 & 9 \\
\hline Note: persons per 1,000 /mo with insurance and usual source of care receiving health care in different settings. \\
\hline
\end{tabular}

care, was associated with an increased likelihood of receiving care in all 5 study settings during a typical month of 1996. Data from the 1996 MEPS indicate that among persons naming an individual health professional as their usual source of care, $93 \%$ specified a primary care physician. Having health insurance also independently predicted a greater likelihood of receiving care in all settings except emergency departments, where by law any person seeking care must be seen. This finding is consistent with other research that shows the important effect of primary care in providing treatment before disease evolution to more severe conditions ${ }^{65-69}$ decreasing emergency department utilization and hospital admissions, ${ }^{70-76}$ and providing preventive services. ${ }^{77-79}$

From a policy perspective, having a usual source of care and health insurance is the most amenable health arrangement to intervention. One can imagine policy options that would assure one or the other or both. Table 3 shows that the effects of these 3 options would likely differ in their impact on where a person receives care. It also shows that their effect would probably be additive, and it makes clear the dramatic differences in health care for persons with both health insurance and a usual source of care compared with those that have neither.

The ecology model organizes complex relationships known to affect health care and the health of populations ${ }^{80}$ It is descriptive rather than prescriptive and does not establish cause-and-effect relationships. What it provides is a framework for considering policy options and designing future research. For example, residence outside an MSA appears to have no independent effect on the likelihood of receiving services in all health care settings, except for a slight reduction in the odds of being seen in a physician's office. To what extent does this finding indicate (1) a rural health policy success, (2) successful adaptation of rural residents to the use of existing resources, (3) greater dependence of rural residents on primary care physicians and less on specialty services, or (4) too gross an aggregation of rural areas to allow detection of as yet unmet needs of some rural populations? The 1996 National Ambulatory Medical Care Survey data give some credence to the third explanation, showing that a greater percentage of the office visits of non-MSA than MSA residents (63\% vs $44 \%$ ) were made to primary care physicians (family physicians, general practitioners, 
general internists, and general pediatricians) ${ }^{81}$ Perhaps in 1996 the only difference in use of ambulatory care services by MSA vs non-MSA residents was less likelihood of rural residents visiting a specialty physician's office. Similarly, further research might inform other options related to patterns revealed by the ecology model, such as the relative advantages and disadvantages of policies focused on education or economic development and assessment of whether it is women or men who require additional attention from the health care enterprise.

This study has limitations other than those already noted. The selected variables and their definitions might not have captured important information. What is a cause and what is a consequence are not clarified, and the available data do not address the content of care in the studied settings. It is important to emphasize the complex pathway from problems to receipt of health care services in different settings. ${ }^{82}$ Also, variation in health care might reflect underuse, overuse, or an appropriate use of services by specific population groups. Perhaps the most important limitation of this study is that it does not enable definitive judgments about the appropriateness of the observed health care patterns.

These results provide policy makers with a menu of potentially important patterns of health care in communities of different sociodemographic composition and health care arrangements. The variation in how subpopulations participate in different health care settings could guide the allocation of resources. Increasing the appropriateness and equity of health care use by offering individuals a usual source of care and providing health insurance coverage are viable policy options that should be considered..$^{83-86}$ The physician's office can be seen to be a logical platform for health education, prevention counseling, chronic disease care, and other activities dependent on sustained partnerships between clinicians and patients; consequently, the design and infrastructures that sustain it are likely to remain central to achieving important policy objectives. ${ }^{87}$

\section{CONCLUSION}

Substantial unexplained variation in the ecology of medical care raises important questions about the equity and effectiveness of the health care system of the United States. It suggests potential effects of some policy options, such as providing everyone with a usual source of care and insurance coverage. The ecology model and its variations can continue to inform and stimulate further examination and assessments of the adequacy and appropriateness of health care for all Americans.
To read commentaries or to post a response to this article, see the online version at http://annfammed/cgi/content/full/1/2/81.

Key words: Medical Economics, Delivery of Health Care, Demography, Demographic and Health Surveys, Ecology

Submitted January 23, 2003; accepted February 10, 2003.

A version of this paper was presented at the North American Primary Care Research Group Annual Meeting, October 14, 2001, Halifax, Canada.

\section{Disclaimer}

The information and opinions contained in research from The Graham Center do not necessarily reflect the views or policy of The American Academy of Family Physicians.

\section{References}

1. White KL, Williams TF, Greenberg BG. The ecology of medical care. N Engl J Med 1961;265:885-892.

2. White K. The ecology of medical care: origins and implications for population-based healthcare research. Health Serv Res 1997;32:11-21.

3. Godwin M, Grzybowski S, Stewart M, et al. Need for an institute of primary care research within the Canadian Institutes of Health Research. Can Fam Physician 1999;45:1405-1409, 1417-1421.

4. DeFriese GH. A brief symposium: In honor of Kerr L. White. Foreword. Health Serv Res 1997;32:3-4.

5. McWhinney IR. An Introduction to Family Medicine. New York, NY: Oxford University Press; 1981

6. Rakel RE. The family physician. In: Rakel R, ed. Essentials of Family Practice. Philadelphia, Pa: WB Saunders Co; 1998:3-20.

7. Task Force on Building Capacity for Research in Primary Care. Putting Research Into Practice: Report of the Task Force on Building Capacity for Research in Primary Care. Bethesda, Md: Agency for Health Care Policy and Research; 1993.

8. Health Resources and Services Administration. Executive summary. The National Primary Care Conference. Washington, DC: US Department of Health and Human Services, Public Health Service, Health Resources and Services Administration; 1992.

9. Green LA, Fryer GE, Yawn BP, Lanier D, Dovey SM. The ecology of medical care revisited. N Engl J Med 2001;344:2021-2025.

10. Fuchs VR. The health sector's share of the gross national product. Science 1990;247:534-538.

11. Aaron $\mathrm{H}$, Schwartz WB. Rationing health care: the choice before us. Science 1990;247:418-422.

12. Marcille JA. The coming boom in primary care. Manag Care 1994; $3(1): 22-24,26-28$.

13. Kuttner R. The American health care system: health insurance coverage. N Engl J Med 1999;340:163-168.

14. Bodenheimer T. The American health care system-physicians and the changing medical marketplace. N Engl J Med 1999;340:584-588.

15. Council on Graduate Medical Education. Fifth Report: Women and Medicine. HRSA-P-DM-95-1. Rockville, Md: US Department of Health and Human Services, Public Health Service, Health Resources and Services Administration; 1995.

16. Iglehart JK. The American health care system - expenditures. N Engl J Med 1999;340:70-76. 
17. Council on Graduate Medical Education: Sixth Report: Managed Health Care: Implications for the Physician Workforce and Medical Education. Rockville, Md: US Department of Health and Human Services, Public Health Service, Health Resources and Services Administration; 1995.

18. Wong MD, Shapiro MF, Boscardin WJ, Ettner SL. Contribution of major diseases to disparities in mortality. N Engl J Med 2002;347: 1585-1592.

19. Govindarajan R, Shah RV, Erkman LG, Hutchins LF. Racial differences in the outcome of patients with colorectal carcinoma. Cancer 2003; 97:493-498

20. Pappas G, Queen S, Hadden W, Fisher G. The increasing disparity in mortality between socioeconomic groups in the United States, 1960 and 1986. N Engl J Med 1993;329:103-109.

21. Singh GK, Yu SM. Infant mortality in the United States: trends, differentials, and projections, 1950 through 2010. Am J Public Health 1995;85:957-964.

22. Geronimus AT. Black/white differences in the relationship of maternal age to birthweight: a population-based test of the weathering hypothesis. Soc Sci Med 1996;42:589-597.

23. Montgomery LE, Kiely JL, Pappas G. The effects of poverty, race, and family structure on US children's health: data from the NHIS, 1978 through 1980 and 1989 through 1991. Am J Public Health 1996;86:1401-1405.

24. Elmore JG, Moceri VM, Carter D, Larson EB. Breast carcinoma tumor characteristics in black and white women. Cancer 1998;83:2509-2515.

25. Trevino RP, Marshall RM Jr, Dale DE, Rodriquez R, Blake G, Gomez J. Diabetes risk factors in low-income Mexican-American children. Diabetes Care 1999:22:202-207.

26. Stancil TR, Hertz-Picciotto I, Schramm M, Watt-Morse M. Stress and pregnancy among African-American women. Paediatr Perinat Epidemiol 2000;14:127-135.

27. Frith-Terhune AL, Cogswell ME, Khan LK, Will JC, Ramakrishnan U. Iron deficiency anemia: higher prevalence in Mexican American than in non-Hispanic white females in the third National Health and Nutrition Examination Survey, 1988-1994. Am J Clin Nutr 2000; 72:963-968

28. Grant EN, Lyttle CS, Weiss KB. The relation of socioeconomic factors and racial/ethnic differences in US asthma mortality. Am J Public Health 2000;90:1923-1925.

29. Brown LM, Hoover $R$, Silverman $D$, et al. Excess incidence of squamous cell esophageal cancer among US Black men: role of social class and other risk factors. Am J Epidemiol 2001;153:114-122.

30. Hillemeier MM, Geronimus AT, Bound SJ. Widening black/white mortality differentials among US children during the 1980s. Ethn Dis 2001;11:469-483.

31. Papacek EM, Collins JW Jr, Schulte NF, Goergen C, Drolet A. Differing postneonatal mortality rates of African-American and white infants in Chicago: an ecologic study. Matern Child Health J 2002; 6:99-105.

32. Chang RK, Chen AY, Klitzner TS. Female sex as a risk factor for inhospital mortality among children undergoing cardiac surgery. Circulation 2002;106:1514-1522.

33. Garg PP, Diener-West M, Powe NR. Income-based disparities in outcomes for patients with chronic kidney disease. Semin Nephrol 2001; 21:377-385.

34. Ibrahim SA, Siminoff LA, Burant CJ, Kwoh CK. Differences in expectations of outcome mediate African American/white patient differences in "willingness" to consider joint replacement. Arthritis Rheum 2002:46:2429-2435.

35. Schoenbaum EE, Lo Y, Floris-Moore M. Predictors of hospitalization for HIV-positive women and men drug users, 1996-2000. Public Health Rep 2002;117(suppl 1):S60-66.

36. Mandell DS, Listerud J, Levy SE, Pinto-Martin JA. Race differences in the age at diagnosis among medicaid-eligible children with autism. J Am Acad Child Adolesc Psychiatry 2002;41:1447-1453.

37. Hawker GA, Wright JG, Glazier RH, et al. The effect of education and income on need and willingness to undergo total joint arthroplasty. Arthritis Rheum 2002;46:3331-3339.

38. Payne R, Medina E, Hampton JW. Quality of life concerns in patients with breast cancer: evidence for disparity of outcomes and experiences in pain management and palliative care among African-American women. Cancer 2003;97(1 suppl):311-317.

39. Moore RD, Stanton D, Gopalan R, Chaisson RE. Racial differences in the use of drug therapy for HIV disease in an urban community. $N$ Engl J Med 1994;330:763-768.

40. Ford ES, Cooper RS. Racial/ethnic differences in health care utilization of cardiovascular procedures: a review of the evidence. Health Serv Res 1995;30(1 pt 2):237-252.

41. Fuentes-Afflick E, Korenbrot CC, Greene J. Ethnic disparity in the performance of prenatal nutrition risk assessment among Medicaid-eligible women. Public Health Rep 1995;110:764-773.

42. Collins JW Jr, Wall SN, David RJ. Adequacy of prenatal care utilization, maternal ethnicity, and infant birthweight in Chicago. J Natl Med Assoc 1997;89:198-203.

43. Zhang P, Tao G, Irwin KL. Utilization of preventive medical services in the United States: a comparison between rural and urban populations. J Rural Health 2000;16:349-356.

44. Ibrahim SA, Siminoff LA, Burant CJ, Kwoh CK. Understanding ethnic differences in the utilization of joint replacement for osteoarthritis: the role of patient-level factors. Med Care 2002;40(1 supp):44-51.

45. Ferris TG, Blumenthal D, Woodruff PG, Clark S, Camargo CA. Insurance and quality of care for adults with acute asthma. J Gen Intern Med 2002;17:905-913.

46. Susan Marquis M, Long SH. The role of public insurance and the public delivery system in improving birth outcomes for low-income pregnant women. Med Care 2002:40:1048-1059.

47. Almeida RA, Dubay LC, Ko G. Access to care and use of health services by low-income women. Health Care Financ Rev 2001;22:27-47.

48. Baker DW, Sudano JJ, Albert JM, Borawski EA, Dor A. Loss of health insurance and the risk for a decline in self-reported health and physical functioning. Med Care 2002;40:1126-1131.

49. Brasel KJ, Rasmussen J, Cauley C, Weigelt JA. Reasons for delayed discharge of trauma patients. J Surg Res 2002;107:223-226.

50. Smith-Campbell B. Access to health care: effects of public funding on the uninsured. J Nurs Scholarsh 2000;32:295-300.

51. Yu SM, Bellamy HA, Kogan MD, Dunbar JL, Schwalberg RH, Schuster MA. Factors that influence receipt of recommended preventive pediatric health and dental care. Pediatrics 2002;110:e73.

52. Sudano JJ Jr, Baker DW. Intermittent lack of health insurance coverage and use of preventive services. Am J Public Health 2003;93:130137.

53. Politzer RM, Yoon J, Shi L, Hughes RG, Regan J, Gaston MH. Inequality in America: The contribution of health centers in reducing and eliminating disparities in access to care. Med Care Res Rev 2001; 58:234-248.

54. Rohrer JE, Vaughn T, Knott A, Westermann J. Health status and health professional visits in a rural area. Health Serv Manage Res 2000;13:127-132.

55. Kelaher M, Stellman JM. The impact of Medicare funding on the use of mammography among older women: Implications for improving access to screening. Prev Med 2000;31:658-664.

56. Weinick RM, Krauss NA. Racial/ethnic differences in children's access to care. Am J Public Health 2000;90:1771-1774.

57. Turner BJ, Cunninham WE, Duan N, Andersen RM, Shapiro MF, Bozzette SA, et al. Delayed medical care after diagnosis in a US 
national probability sample of persons infected with human immunodeficiency virus. Arch Intern Med 2000;160:2614-2622.

58. Sarver JH, Cydulka RK, Baker DW. Usual source of care and nonurgent emergency department use. Acad Emerg Med 2002;9:916-923.

59. Corbie-Smith G, Flagg EW, Doyle JP, O'Brient MA. Influence of usual source of care on differences by race/ethnicity in receipt of preventive services. J Gen Intern Med 2002;17:458-464.

60. Shi L, Starfield B, Politzer R, Regan J. Primary care, self-rated health, and reductions in social disparities in health. Health Serv Res 2002; 37:529-550.

61. Devoe J, Fryer GE, Hargraves JL, Phillips RL, Green LA. Does career dissatisfaction affect the ability of family physicians to deliver highquality patient care? J Fam Pract 2002;51:223-228.

62. Breen N, Wagener DK, Brown ML, Davis WW, Ballard-Barbash R. Progress in cancer screening over a decade: results of cancer screening from the 1987, 1992, and 1998 National Health Interview Surveys. J Natl Cancer Inst 2001;93:1704-1713.

63. Cunningham PJ, Trude S. Does managed care enable more low income persons to identify a usual source of care: Implications for access to care. Med Care 2001;39:716-726.

64. MEPS: Household Component Event Files. Rockville, Md: Agency for Healthcare Research and Quality; 2001.

65. Franks P, Clancy CM, Nutting PA. Gatekeeping revisited-protecting patients from overtreatment. N Engl J Med 1992;327:424-429.

66. Gonnella J, Cattani J, Louis D, et al. Use of outcome measures in ambulatory care evaluation. In: Gebink G, White N, Eaden J, eds. Ambulatory Medical Care - Quality Assurance. La Jolla, Calif: La Jolla Health Science Publications; 1977.

67. Shea S, Misra D, Ehrlich MH, Field L, Francis CK. Predisposing factors for severe, uncontrolled hypertension in an inner-city minority population. N Engl J Med 1992;327:776-781.

68. Ferrante JE, Gonzales EC, Pal N, Roetzheim RG. Effects of physician supply on early detection of breast cancer. J Am Board Fam Pract 2000;13:408-414.

69. Gadomski A, Jenkins P. Ruptured appendicities among children as an indicator of access to care. Health Serv Res 2001;36:129-142.

70. Bindman AB, Grumbach $K$, Osmond $D$, et al. Preventable hospitalizations and access to health care. JAMA 1995;274(4):305-311.

71. Wasson J, Sauvigne A, Mogielnicki R et al. Continuity of outpatient medical care in elderly men. A randomized trial. JAMA 1984;252 (17):2413-2417.
72. Hochheiser LI, Woodward K, Charney E. Effect of the neighborhood health center on the use of pediatric emergency departments in Rochester, New York. N Engl J Med 1971;285:148-152.

73. Alpert JJ, Robertson LS, Kosa J, et al. Delivery of health care for children: report of an experiment. Pediatrics 1976;57:917-930.

74. Hurley RE, Freund DA, Taylor DE. Emergency room use and primary care case management: evidence from four medicaid demonstration programs. Am J Public Health 1989;79:843-846.

75. Parchman ML, Culler S. Primary care physicians and avoidable hospitalization. J Fam Pract 1994;39:123-128.

76. Starfield B. Access - perceived or real, and to what? JAMA 1995; 274:346-347.

77. Dietrich AJ, Goldberg H. Preventive content of adult primary care: do generalists and subspecialists differ? Am J Public Health 1984; 74:223-227.

78. Bindman $A B$, Grumbach $K$, Osmond D, et al. Primary care receipt of preventive services. J Gen Intern Med 1996;11:269-276.

79. Dovey SM, Green LA, Fryer GE. Educating doctors to provide counseling and preventive care: turning 20th century professional values head over heels. Educ Health 2000;13:307-316.

80. Alcock P, Glennerster H, Oakley A, Sinfield A. Welfare and Wellbeing. Bristol, England: Policy Press; 2001.

81. 1996 NAMCS data file. CDC: National Center for Health Statistics. Available at: http://www.wonder.cdc.gov/wonder/sci_data/surveys/ namcs/type_txt/namcs96.asp. Accessed June 2003.

82. Moynihan R, Smith R. Too much medicine? BMJ 2002;324:859-860.

83. Hoffman B. Health care reform and social movements in the United States. Am J Public Health 2003;93:75-85.

84. Derickson A. "Health for three-thirds of the nation:" public health advocacy of universal access to medical care in the United States. Am J Public Health 2002;92:180-190.

85. Shaffer ER. Universal coverage and public health: new state studies. Am J Public Health 2003;93:109-111.

86. Oberlander LJ. The US health care system: on a road to nowhere? CMAJ 2002;167:163-168.

87. Donaldson MS. Primary Care: America's Health in a New Era. Washington, DC: National Academy Press; 1996. 